\title{
ERYTHRASMA IN NORMAL YOUNG ADULTS
}

\author{
DOROTHY A. SOMERVILLE* \\ Department of Bacteriology, St John's Hospital, London, W.C.2
}

ERYTHRASMA is a superficial infection of the skin which in temperate climates predominantly affects intertriginous sites, particularly the groin, toe-webs and axillae. Lesions are well defined, scaling and slightly brown or red in colour. In tropical and subtropical climates a more widespread form may be seen and any part of the skin can be involved. Characteristically, lesions of erythrasma fluoresce coral-red when viewed by Wood's light; mild subclinical cases are frequently seen and are diagnosed in this way.

This infection of the skin has been variously described as caused by a fungus, Microsporum minutissimum, an actinomycete, Nocardia minutissimum, and a Bacillus species. Most recently, a diphtheroid Corynebacterium minutissimum (Sarkany, Taplin and Blank, 1961a) has been implicated; this organism when grown on tissue-culture medium no. 199 containing 20 per cent. calf serum and viewed by Wood's light, fluoresces a coral-red colour similar to that seen with the lesion. Experimental infection of the human forearm with strains of diphtheroids isolated from clinical cases of erythrasma has reproduced the fluorescent condition, although the lesions produced resolved within a few days (Sarkany, Taplin and Blank, 1961b). It seems probable that $C$. minutissimum can live on the skin without causing any symptoms of infection and that it is a member of the normal skin flora, for it has been isolated from the normal skin area (Marples, 1965; Burns et al., 1967). Under conditions leading to erythrasma it may multiply to become a major member of the bacterial flora, producing fluorescent patches in the skin.

All age groups appear to be affected, but detailed studies regarding age and sex incidence and carriage of the fluorescent diphtheroids amongst the normal population are not available. This paper reports an investigation of groups of healthy young adults living in various Colleges of Education.

\section{MATERIALS AND METHODS}

A total of 754 students attending eight different colleges were included in the survey; there were 514 males and 240 females. The toe-webs, axillae and groins were examined by Wood's light and swabbed with moistened cotton-wool swabs. Note was made of any fluorescence, scaling or maceration of the area. Swabs were plated directly on tissueculture medium no. 199 (Glaxo) containing 20 per cent. calf serum (Oxoid), 0.5 per cent. tris (hydroxymethyl) aminomethane and 2 per cent. agar. Sodium bicarbonate, antibiotics and phenol red were omitted from the medium no. 199. No advantage was found in substituting autoclaved for unautoclaved calf serum (Sarkany, Taplin and Blank, 1962), nor was the use of autoclaved egg-white advantageous, for, of 100 strains of $C$. minutissimum fluorescent on 199 medium with calf serum, only 6 fluoresced on the medium with egg-white. Plates were used within 7-10 days of preparation. Plates were incubated at $37^{\circ} \mathrm{C}$ and were examined for culture fluorescence after 18 and $36 \mathrm{hr}$. Cultures showing fluorescence were

Received 25 Apr. 1969; accepted 17 June 1969.

* M.R.C. Research Fellow.

J. MED. MICROBIOL.-VOL. 3 (1970) 
subcultured on blood agar and individual colonies representing apparently different strains were retested for fluorescence on 199 medium before further identification was attempted. Only organisms fluorescing coral-red on 199 medium were studied.

The majority of these isolates were diphtheroids defined for the purposes of this paper as Gram-positive, non-branching, pleomorphic rods with metachromatic granules. The following biochemical tests were performed on all these organisms: fermentation of glucose, lactose, maltose, sucrose, fructose, galactose, mannose, inulin, salicin, dextrin; production of urease, catalase, oxidase, indole and acetoin; reduction of nitrate; and the methyl red test. Lipolytic and lipophilic properties were also tested. Sugar fermentation was tested in 5 per cent. serum sugar medium, containing 1 per cent. of the appropriate sugar, and lipophilic and

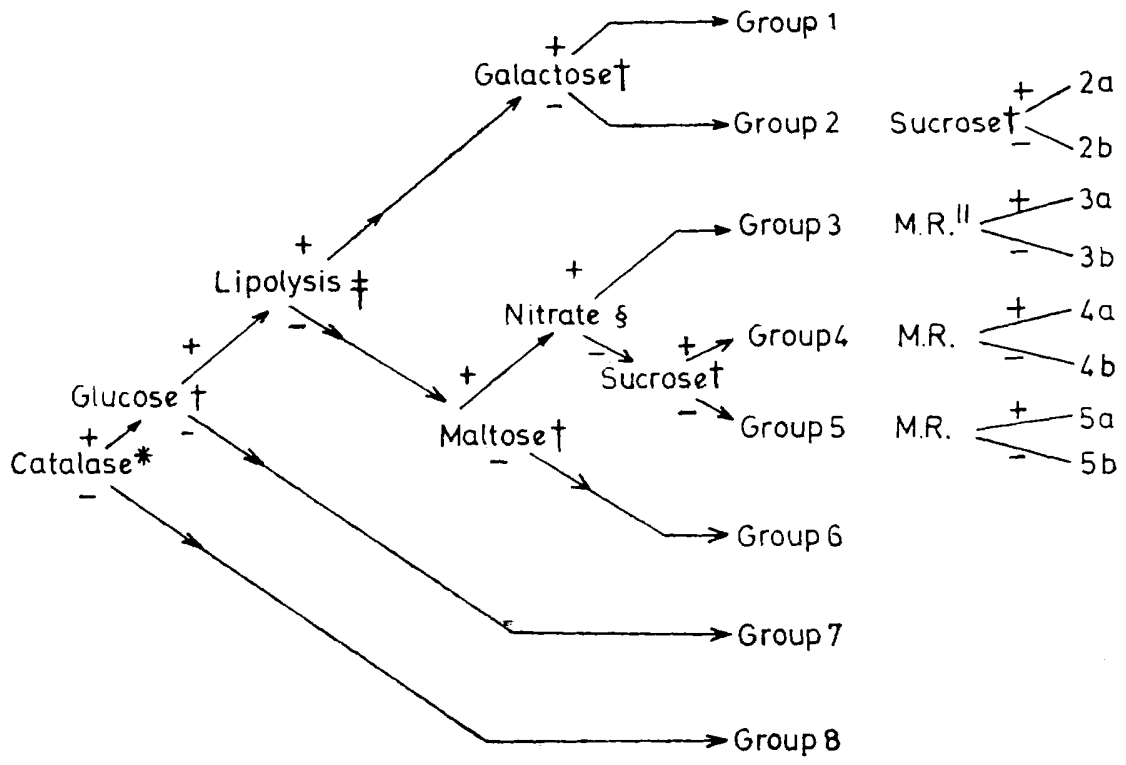

Fic. 1.-Scheme for the grouping of fluorescent diphtheroid organisms isolated from the skin.

* Catalase test,$+=$ catalase produced, $-=$ catalase not produced; $\dagger$ sugar fermentation tests, $+=$ acid produced, $-=$ acid not produced; $\ddagger$ lipolysis test,$+=$ lipolysis observed, $-=$ lipolysis not demonstrated; $\S$ nitrate reduction test, $+=$ nitrate reduced, $-=$ nitrate not reduced; II methyl red test, $+=$ positive result, $-=$ negative result. See text for details of the tests employed.

lipolytic properties were tested on nutrient agar containing 1 per cent. Tween 80 . Lipophilic diphtheroids produced larger colonies on this medium than on nutrient agar alone and lipolytic diphtheroids were identified by the production of a precipitate around their colonies on this medium. A 48-hr peptone water culture of the diphtheroid was used to provide the inoculum for all test media, and all tests, except for catalase and oxidase production and lipolytic and lipophilic properties, were read after incubation of the cultures for $1 \mathrm{wk}$ at $37^{\circ} \mathrm{C}$. The other tests were completed after $48 \mathrm{hr}$ at $37^{\circ} \mathrm{C}$. Methods used were those described by Cowan and Steel (1965). On the basis of the results of eight tests-lipolysis, catalase production, reduction of nitrate, acid production from glucose, maltose, sucrose and galactose and the methyl red (MR) test-it was possible to divide the isolates of fluorescent diphtheroids into eight different biochemical groupings (fig. 1). A small proportion (11 per cent.) of the original fluorescent isolates were Gram-positive cocci, and these were grouped according to the scheme published by Baird-Parker (1963). All retained the property of fluorescence after several subcultures. No organism belonging to the genus Bacillus, similar to that isolated by Partridge and Jackson (1962), was obtained from any skin site. 
One college was visited twice at an interval of $3 \mathrm{mth}$ and a different population sampled. It was then revisited after $1 \mathrm{yr}$ and 108 students were re-examined to determine the difference in the infection rate after this interval. When first examined, the students were seen within a few days of their arrival at the college, but at the re-examination they had been living in the semi-closed community for a year.

TABLE I

Incidence of clinical erythrasma in an adult population

\begin{tabular}{l|c|c|c|c|c}
\hline \multirow{1}{*}{ Population } & Number examined & \multicolumn{3}{|c}{ Percentage with detectable erythrasma } \\
& & & \multicolumn{2}{|c}{ affecting } \\
& & axillae & groins & toe-webs & any site \\
\hline Males & 514 & 3 & 3 & 16 & 20 \\
Females & 240 & 0 & 2 & 16 & 18 \\
\hline Total & 754 & 2 & 3 & 16 & 19 \\
\hline
\end{tabular}

The use of deodorants, treatment of the toe-webs with anti-fungal preparations, complaints of athlete's foot and any other signs or symptoms of infection relating to any of the three skin sites were noted on a questionnaire form. It was possible to obtain the somatotypes of 131 of the male students and I am most grateful to Dr H. E. Robson, Loughborough College of Education, for permission to use these results.

TABLE II

Carriage rate of fluorescent diphtheroid organisms in non-fuorescent skin sites

\begin{tabular}{l|c|c|c|c}
\hline Sex & Number examined & \multicolumn{2}{|c}{$\begin{array}{c}\text { Percentage with fluorescent diphtheroid } \\
\text { organisms in non-fluorescent sites in }\end{array}$} \\
\hline & & axillae & groins & toe-webs \\
\hline Males & 514 & 12 & 13 & 16 \\
Females & 240 & 3 & 20 & 5 \\
\hline
\end{tabular}

\section{RESULTS}

Of the 754 students examined for the first time, 144 (19 per cent.) were found to have erythrasma. None of the affected students complained of any discomfort; the diagnosis was made solely on the presence of coral-red fluorescence in any of the test skin sites. There was no difference in the incidence of detectable erythrasma between males and females (table I). The commonest areas infected were the toe-webs, particularly the fourth toe-web, and scaling was seen in 97 per cent. of the affected toe-webs.

Fluorescent diphtheroids were isolated from 42 per cent. of the sites that fluoresced and from 13 per cent. of the non-fluorescent sites. In the male 
respondents, there was a similar carriage rate in all three sites, but in the females, the rates of isolation of these organisms differed for the different sites (table II). Carriage rates for these non-fluorescent sites were significantly different in the two sexes: axillae $\chi^{2}=16.8, \mathrm{P}<0.001$; groins $\chi^{2}=7.7,0.001<\mathrm{P}<0.01$; toe-webs $\chi^{2}=15 \cdot 1, \mathrm{P}<0 \cdot 001$. Scaling was found to be associated with clinically evident erythrasma, but not with the isolation of fluorescent diphtheroids from non-fluorescent sites (table III).

TABLE III

Association of erythrasma with scaling of the toe-webs

\begin{tabular}{l|c|c|c}
$\begin{array}{c}\text { Clinical } \\
\text { assessment }\end{array}$ & $\begin{array}{c}\text { Number } \\
\text { examined }\end{array}$ & $\begin{array}{c}\text { Percentage with detectable } \\
\text { erythrasma }\end{array}$ & $\begin{array}{c}\text { Percentage with fluorescent } \\
\text { diphtheroid organisms on } \\
\text { non-fluorescent site }\end{array}$ \\
\hline Scaling present & 274 & 42 & 10 \\
Scaling absent & 480 & 1 & 11 \\
\hline
\end{tabular}

The incidence of clinical erythrasma was similar throughout the population studied (table IV), but two colleges had a much higher incidence of fluorescent diphtheroids found on non-fluorescent sites. There was no evidence from

TABLE IV

Incidence of erythrasma in different communities

\begin{tabular}{|c|c|c|c|c|c|c|c|}
\hline \multirow{2}{*}{ College } & \multirow{2}{*}{$\begin{array}{l}\text { Number } \\
\text { of persons } \\
\text { examined }\end{array}$} & \multicolumn{3}{|c|}{$\begin{array}{l}\text { Percentage with detectable } \\
\text { erythrasma affecting }\end{array}$} & \multicolumn{3}{|c|}{$\begin{array}{l}\text { Percentage with fluorescent } \\
\text { diphtheroid organisms on non- } \\
\text { fluorescent site }\end{array}$} \\
\hline & & axillae & groins & toe-webs & axillae & groins & toe-webs \\
\hline $\begin{array}{l}1 \mathrm{~A} \\
1 \mathrm{~B} \\
2 \\
3 \\
4 \\
5 \\
6 \\
7 \\
8\end{array}$ & $\begin{array}{r}123 \\
141 \\
167 \\
32 \\
37 \\
53 \\
145 \\
28 \\
23\end{array}$ & $\begin{array}{l}0 \\
0 \\
7 \\
6 \\
0 \\
0 \\
0 \\
0 \\
0\end{array}$ & $\begin{array}{l}0 \\
6 \\
5 \\
3 \\
0 \\
0 \\
1 \\
7 \\
0\end{array}$ & $\begin{array}{r}10 \\
16 \\
17 \\
9 \\
27 \\
12 \\
16 \\
21 \\
22\end{array}$ & $\begin{array}{r}2 \\
14 \\
21 \\
13 \\
3 \\
2 \\
4 \\
4 \\
4\end{array}$ & $\begin{array}{r}2 \\
7 \\
25 \\
9 \\
5 \\
15 \\
4 \\
18 \\
22\end{array}$ & $\begin{array}{r}6 \\
10 \\
26 \\
6 \\
5 \\
0 \\
25 \\
4 \\
13\end{array}$ \\
\hline
\end{tabular}

somatotypes that erythrasma was found more commonly in the more heavily built males. The use of deodorants did not appear to reduce the incidence of erythrasma, nor the isolation of fluorescent diphtheroids (table V).

The fluorescent diphtheroids were divided on the basis of eight biochemical tests into eight groups. There did not seem to be one particular group associated with clinical lesions, and there was no evidence of any one strain predominant in the different colleges. All biochemical types were isolated both from lesions and from healthy skin (fig. 2). 
The students re-examined after a year of institutional life had both a higher incidence of clinical erythrasma and an increased carriage rate of fluorescent

TABLE V

Effect of deodorants on the incidence of detectable erythrasma and the presence of fluorescent diphtheroid organisms in the axillae of male and female adults

\begin{tabular}{|c|c|c|c|c|c|c|}
\hline \multirow{2}{*}{$\begin{array}{c}\text { Deodorant } \\
\text { history }\end{array}$} & \multicolumn{2}{|c|}{$\begin{array}{l}\text { Number of } \\
\text { subjects } \\
\text { examined }\end{array}$} & \multicolumn{2}{|c|}{$\begin{array}{c}\text { Percentage and sex } \\
\text { of subjects with } \\
\text { detectable erythrasma* }\end{array}$} & \multicolumn{2}{|c|}{$\begin{array}{c}\text { Percentage and sex } \\
\text { of subjects with } \\
\text { fluorescent diphtheroid } \\
\text { organisms* }\end{array}$} \\
\hline & Male & Female & Male & Female & Male & Female \\
\hline $\begin{array}{l}\text { Deodorant } \\
\text { used }\end{array}$ & 117 & 198 & 3 & 0 & 14 & 3 \\
\hline $\begin{array}{r}\text { Deodorant } \\
\text { not used }\end{array}$ & 397 & 42 & 3 & 0 & 13 & 2 \\
\hline
\end{tabular}

diphtheroids on non-fluorescent sites (table VI). The increased incidence of clinical erythrasma was particularly obvious in the groins $(0.001<\mathrm{P}<0.01)$.
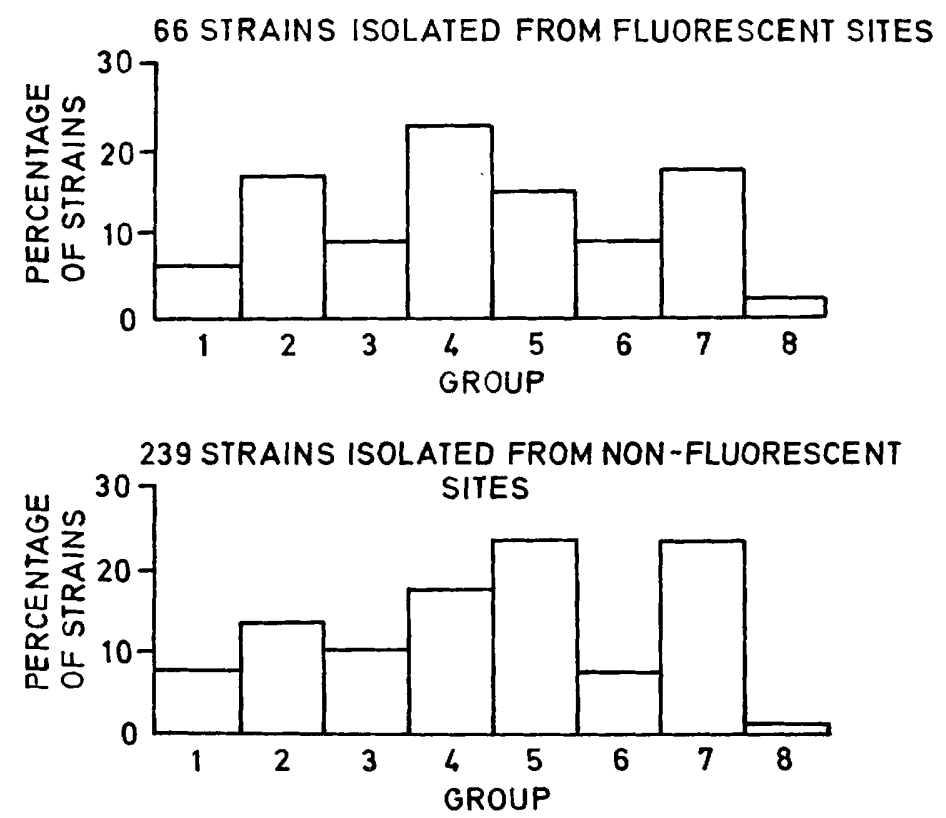

FIG. 2.-The distribution of isolated strains of fluorescent diphtheroid organisms within the eight biochemical groups.

Of those students infected at the first visit, 93 per cent. were still affected in some way at the second visit, 42 per cent. still with clinical erythrasma. No 
particular strain of diphtheroid was involved and it appeared that there was simply an increase in the number of isolations of all strains from the various sites.

Micrococci also fluorescing on TC Medium 199 were isolated from 40 sites and were sometimes the only fluorescent organisms isolated from a fluorescent site. On the basis of the reactions of these organisms in the tests suggested by Baird-Parker, 39 isolates were found to belong to Micrococcus group 8 and one to Micrococcus group 5.

TABLE VI

Incidence of erythrasma in a group of 108 adults sampled on two occasions at an interval of 10 months

\begin{tabular}{l|c|c|c|c}
\hline \multirow{1}{*}{$\begin{array}{c}\text { Site } \\
\text { involved }\end{array}$} & \multicolumn{2}{|c|}{ Percentage with detectable erythrasma } & \multicolumn{2}{|c|}{$\begin{array}{c}\text { Percentage with fluorescent diphtheroid } \\
\text { organisms on apparently healthy site }\end{array}$} \\
\cline { 2 - 5 } & 1st examination & 2nd examination & 1st examination & 2nd examination \\
\hline $\begin{array}{l}\text { Axillae } \\
\text { Groins } \\
\text { Toe-webs }\end{array}$ & 0 & 0 & 13 & 35 \\
& 15 & 19 & 16 & 30 \\
\hline
\end{tabular}

\section{Discussion}

The incidence of erythrasma found in the present survey of young adults is very similar to that found by other workers (Sarkany et al., 1962; Temple and Boardman, 1962; Munro-Ashman, Wells and Clayton, 1963; Burns et al., 1967), though lower than the 37 per cent. reported by English and Turvey (1968). However, this survey included subjects belonging to older age-groups and the incidence of erythrasma has been shown to increase with age (Somerville et al., 1970). In the present study there was no such increase of erythrasma within the limited range of age-groups represented. Michalowski and Rodziewitcz $(1965,1966)$, however, found a low incidence of erythrasma (12 per cent.) in groups of elderly men and women, similar to the infection rate found in the present survey of young adults. English and Turvey diagnosed erythrasma solely on the fluorescence of the skin affected as they found difficulty in isolating the associated diphtheroid organisms. In the present survey, fluorescent diphtheroids were isolated from only 42 per cent. of the fluorescent sites. A more efficient sampling method or an enrichment technique may be necessary before isolations can be made from all lesions.

No difference in the incidence of erythrasma was seen between the male and female respondents. Tinea pedis is generally found more commonly in males than in females (Marples, 1965; English and Turvey), but the condition was uncommon in the present survey. There was, however, a sex difference in the carriage of fluorescent diphtheroids on non-fluorescent sites, with a lower 
incidence in the axillae and toe-webs of females, but a higher incidence in female groins. This may be attributable to differences in hygiene, though the use of deodorants did not reduce the carriage rate of fluorescent diphtheroids in the axillae and there appears to be an intrinsic difference in the carriage of these organisms in the males and females. Shehadeh and Kligman (1963) found that the predominant effect of the use of deodorants was a reduction in the incidence of Gram-positive organisms, particularly the diphtheroids, which appear to play a major role in the production of axillary odour. This does not seem to happen in the case of fluorescent diphtheroid organisms. In a survey of erythrasma in a mental hospital (Somerville et al.) personal cleanliness was found to produce a significant reduction in the carriage of diphtheroids in non-fluorescent skin areas, though hygiene did not appear to affect the incidence of clinical infection directly. However, differences in hygiene were greater in these patients than in the students.

Fine scaling of the skin of the axilla and groin or mild to severe scaling in the toe-webs accompanied site fluorescence in the majority of cases. However, there were 6 cases with no symptoms and in which no signs were seen when sites were examined by ordinary light. Similar occurrences of fluorescence in lesionfree patients have been reported by Ayres and Mihan (1968) and English and Turvey. Moreover, fluorescent diphtheroids were isolated from 13 per cent. of non-fluorescent sites. These observations support the belief (Marples; Burns et al.) that Corynebacterium minutissimum is a member of the normal flora of the skin, acting as an opportunist pathogen under suitable conditions. Biochemical findings suggest too that the name $C$. minutissimum covers a complex of organisms, encompassing a number of biochemically different fluorescent diphtheroids. The strain isolated by Sarkany and his co-workers $(1961 b)$ was obtained from the National Collection of Type Cultures (NCTC10288) and subjected to the same tests as those strains isolated in the present series. It was placed in group 2. It should be noted that fluorescent diphtheroids were not the only organisms isolated from the specimens taken in the present study. Of 40 strains of fluorescent micrococci isolated, 39 were found to belong to Micrococcus group 8 and one to Micrococcus group 5.

Kooistra (1965) also suggested that erythrasma may spread through an institution. In the college that was visited twice at an interval of $3 \mathrm{mth}$ and a different population sampled, incidences of erythrasma and fluorescent diphtheroids were similar at both times. When 108 respondents were re-examined after a lapse of $10 \mathrm{mth}$, the majority of those infected at the first examination were found to be affected again at the second. The status had changed from clinically infected to symptomless carriage of the organisms in a non-fluorescent site in 6 , but had changed from carriage to clinical infection in 5 . There were 4 subjects from whom the biochemical type of fluorescent diphtheroid isolated was unchanged on the second occasion; in 4 cases the type changed. Mild infections with erythrasma and carriage of fluorescent diphtheroids can persist for long periods without causing any undue discomfort to the subject. Spread of the organisms among the college population appears to have taken place though no one type of diphtheroid was found to predominate. 


\section{SUMMARY}

An investigation of the incidence of erythrasma in a healthy young adult population is described. The axillae, groins and toe-webs were examined and clinical erythrasma, showing characteristic coral-red fluorescence under Wood's light, was found in 19 per cent. of the 754 students, with lesions occurring mainly in the toe-webs. A diphtheroid organism, fluorescing when grown on tissue culture medium no. 199, could be cultured from 42 per cent. of the fluorescent skin areas and from 13 per cent. of apparently healthy, non-fluorescing sites. These organisms were divided into 8 groups on the basis of their reactions in 8 biochemical tests. There did not appear to be one particular group involved with clinical lesions, nor was any one strain predominant among the students and staff of the different colleges visited.

I am indebted to the staff and students who took part in this survey at the various colleges and I wish to thank the many people involved in collecting the specimens.

\section{REFERENCES}

Ayres, S., AND Mihan, R. . ～. . 1968. Archs Derm., 97, 173.

Baird-Parker, A. C. . . . . 1963. J. Gen. Microbiol., 30, 409.

Burns, R. E., Greer, J. E., Mikhail, G., 1967. Archs Derm., 96, 436. AND LIVINGOOD, C. S.

CowAN, S. T., AND SteEl, K. J. - 1965. Manual for the identification of medical

ENGlish, MARY P., AND TuRvey, J. $\quad$. 1968. Br. Med. J., 4, 228.

Kooistra, J. A. . . . . . 1965. J. Invest. Derm., 45, 399.

MARPLES, MARY J. . . . . . 1965. The ecology of the human skin, Spring-

MichalowsKi, R., AND Rodziewitcz, 1965. Archs Derm., 92, 396. HELENA

$\begin{array}{llll}\text { Munro-Ashman, D., Wells, R. S., AND } & \text { 1966. } & \text { Derm. Wschr., 152, } 535 . \\ \text { Mr. J. Derm., 75, } 401 .\end{array}$

Clayton, Yvonne M.

Partridge, Betty M., AND JaCkson, F. L. 1962. Ibid., 74, 326.

SARKany, I., TAPlin, D., AND BlaNK, H. 1961a. J. Invest. Derm., 37, 283.

" " " " " $\quad$ 1961b. J. Amer. Med. Assoc., 177, 130.

" " " " " " 1962. Archs Derm., 85, 578.

Shehadeh, N. H., and Kligman, A. M. 1963. J. Invest. Derm., 41, 3.

Somerville, Dorothy A., Seville, R. H., $1970 . \quad B r . J . D e r m ., ~ 82$, in press. Cunningham, R. C., Noble, W. C., AND SaVin, J. A.

Temple, D. E., ANd Boardman, C. R. - 1962. Archs Derm., 86, 518. 